\title{
Okul öncesi dönem çocuğu olan ebeveynlerin ebeveynlik tutumlarının incelenmesi
}

\author{
Investigation of parenting attitudes of parents whose children are at \\ preschool age
}

Erhan Alabay ${ }^{1}$

\begin{abstract}
Öz: Bu araştırmanın amacı, 48-72 aylık çocuğu olan anne ve babaların, çocuklarını yetiştirirken gösterdikleri ebeveyn tutumlarının farklı değişkenlere dayalı olarak incelenmesidir. Araştırmada nicel araştırma desenlerinden betimsel tarama modeli uygulanmıştır. Veri toplama aracı olarak Demir ve Şendil (2008) tarafından geliştirilen toplam 46 maddeden oluşan ve ebeveynlerin çocuk yetiştirmedeki demokratik, otoriter, aşırı koruyucu ve izin verici tutumlarını belirleyen "Ebeveyn Tutum Ölçeği (ETÖ)" kullanılmıştır. Araştırmanın örneklemini İstanbul ili Pendik ilçesinde tesadüfi örnekleme yöntemine uygun olarak belirlenmiş toplam 422 ebeveyn oluşturmaktadır. Araştırma kapsamında ebeveynlerin cinsiyeti, öğrenim durumu, ortalama geliri, aile yapısı, çocuk sayısı, çocuk gelişimi ile ilgili seminere katılma durumu, çocuğu ile geçirilen zaman ve çocuğun cinsiyeti bağımsız değişken olarak belirlenmiş ve bağımlı değişken olan ebeveyn tutum puanları arasında anlamlı bir farklılaşmanın olup olmadığı incelenmiştir. Veri analizleri sonucunda, çalışmayan ebeveynlerin, çalışan ebeveynlere oranla daha koruyucu bir tutum içinde olduğu, ebeveynlerin çocuk gelişimi ile ilgili seminere katılma durumlarının otoriter ve aşırı koruyucu tutum puan ortalamalarını düşürdüğü ve ebeveynlerin kız çocuklarına oranla erkek çocuklarına daha otoriter bir tutum sergilediği sonucuna ulaşılmıştır. Aynı zamanda araştırma bulguları doğrultusunda, ebeveynlerin yaş, öğrenim durumu, gelir düzeyi ve çocuk sayısı bağımsız değişkeni ile ebeveyn tutum ölçeği alt boyut puanları arasında da anlamlı bir farklılaşmaya rastlanmıştır.
\end{abstract}

Anahtar Kelimeler: Ebeveyn, ebeveynlik tutumları, okul öncesi, çocuk

\begin{abstract}
The purpose of this study is to examine parental attitudes of parents with children between 48-72 months old, depending upon different variables while they are raising their children. Out of quantitative research patterns, descriptive survey model was used in the research. As data collecting tool, Parental Attitude Scale (PAS), developed by Demir and Şendil (2008) and which consists of 46 items in total and determines democratic, authoritative, overprotective, and permissive attitudes of parents in raising children was used. The sample of the research was composed of 422 parents who were selected in accordance with random sampling method and residing in İstanbul Province, Pendik District. Within context of the research, gender of parents, educational background, average income, family structure, number of children, whether or not they joined a seminar on pediatric development, the amount of time they spend with their child and the gender of the child were determined as independent variables and it was examined, based on these independent variables, whether there is a significant difference in parental attitude points which are dependent variables. In the analysis of data obtained from the research, it was concluded that non-employed parents are relatively more protective than employed parents, the fact that parents joined a seminar on pediatric development decreased the authoritative and overprotective attitude average points and parents adopted a more authoritative manner towards boys compared to girls. Also, in line with research findings, a significant difference was detected on parental attitude scale sub-dimension points depending on the independent variables of parents' ages, educational background, income level and number of children.
\end{abstract}

Keywords: Parent, parental attitudes, preschool, child

\footnotetext{
${ }^{1}$ İstanbul Aydın Üniversitesi, Sağlık Bilimleri Fakültesi, Çocuk Gelişimi Bölümü, erhanalabay@gmail.com
} 


\section{SUMMARY}

\section{Introduction}

The main purpose of this study is to examine parental attitudes of parents with children between 48-72 months old, depending upon different variables while they are raising their children. Accordingly, the main problem question of the research is as noted below.

'Do parental attitudes of parents who have children between 48-72 differ depending upon their some variables?

In line with main problem question, answers are sought for those sub-problems in the research:

a. What are the frequency-analysis percentages for the parental attitudes of parents who joined the research?

b. Is there a significant difference in parental attitudes of parents who joined the research depending upon the independent variables of their gender, employment status, family structure, seminar attendance and their child's gender?

c. Is there a significant difference in parental attitudes of parents who joined the research depending upon the independent variables of their age, education, income level, number of children and the time spent with children?

\section{Method}

This study is a quantitative research and findings were obtained through survey model. Out of general survey models, the research was carried out using descriptive survey model. By using random sampling method within İstanbul province, Pendik district, the research, in accordance with its aim, covered 422 parents with 48-72-month-old children. Within the context of the research, demographic information form developed by the researcher and 'Parental Attitude Scale' developed by Karabulut Demir and Şendil (2008) were used. Demographic information form was developed by the researcher and consisted of 10 questions with the aim of determining parents' demographic information. In this form, it was aimed to determine parents' ages, educational backgrounds, income and employment status, family structure, number of children and their gender, dealing time with children and whether the parents attended a seminar related to pediatric development. Parental Attitude Scale was developed by Karabulut Demir and Şendil (2008) with the aim of determining parents' attitude towards children between 2 and 6 ages. The scale, appropriate to be conducted for parents who have children between 2 and 6 , was composed of 4 sub-dimensions including democratic (17 items), authoritative (11 items), overprotective (9 items), permissive (9 items) and 46 items in total. 


\section{Results}

Majority of the 422 parents $(\% 83,9)$ joining the research showed an approach of democratic attitude towards their children. It was concluded that, among the rest of the parents, $\% 9$ of them were overprotective, $\% 6,2$ were permissive and $\% 9$ had an authoritative attitude towards their children. It was detected that employed parents, at a significant rate, showed a more overprotective attitude to their children in comparison to the non-employed. It was also noted that parents who attended a pediatric seminar showed a more authoritative and overprotective attitude to their children in comparison to the parents who didn't. Parents who have a son turned out to behave more authoritatively in comparison to the parents who have a daughter. As part of the research, it was found that parents between the ages of 26-30/31-35 and 36-40 displayed a more democratic attitude in comparison to those between 20 and 25 . Besides, parents who have an only child showed a less authoritative attitude towards their children in comparison to those who have three or more children. Additionally, it was found in the research that there is a significant difference in overprotective attitude average points depending upon the educational status of the parents. It was concluded that postgraduate parents exhibited a less overprotective manner to their children compared to the parents who are primary school graduate and parents who have associate degree. Moreover, depending upon the income level of the family, a significant difference was seen on overprotective attitudes. Parents who have an income level between 0-1000 tl were seen to behave more over-protectively towards their children compared to those who have an income level of $3000 t 1$ and more. As a last point, it was concluded that parents who have two children acted in a less permissive way to their children in comparison to those who have three or more children. Following recommendations can be suggested in accordance with the findings of the research carried out to examine parental attitudes of parents with preschool children, depending upon different variables while they are raising their children.

- Within the context of collective projects, universities, non-governmental organizations and, municipal corporations can organize free seminars, courses and workshops for parents.

- Bulletins regarding parental attitudes can be prepared periodically and distributed in the areas with low socio-economic level.

- Assembling regular meetings, teachers can express appropriate parental attitudes for the parents whose children attend preschool.

- Public service announcements concerning parental attitudes can be prepared and broadcasted on T.V, today's most influential communication means, through national or international channels.

So as to reduce the negative effects of undesirable attitudes and to raise the child in a democratic way, not only should parents be trained, but everyone else within the social environment of the child should be educated, as well. 


\section{GİRIŞ}

Çocuk dünyaya geldiği andan itibaren, ebeveynleri tarafından sevgiye, ilgiye ve ihtiyaçlarının karşılanmasına ihtiyaç duyar. Bu gereksinimler doğrultusunda ebeveynler kendi yetiştirilme tarzı, sosyal çevreden gözlemleri ve öğrenim süresince öğrendiği bilgileri kullanarak çocuğunu yetiştirir. Bunun haricinde birçok değişken ailenin çocuğu yetiştirme tarzını etkilemektedir (Demiriz ve Öğretir, 2007; Demirutku, 2007). Örneğin ailenin içinde yaşadığı toplumun kültür yapısı, anne-baba arasındaki ilişki, sosyoekonomik yapısı, öğrenim durumları, anne babanın mesleği, çocuğun yaşı ve hatta çocuğun cinsiyetine göre değişiklik gösterebilmektedir (Özerk, 2006; Savran ve Kuşin, 1997; Şahin ve Özyürek, 2008). Bu nedenle çocuk yetiştirme stilleri ebeveynler arasında farklılaşmalara neden olmaktadır. Fakat anne ve babaların çocuklarına sergiledikleri çocuk yetiştirme stilleri çocuğun ileride göstereceği davranış1 etkileyeceği kanıtlanmış ve ebeveynlerin çocuk yetiştirme tutum ve davranışlarının hayati bir önemi olduğu anlaşılmıştır (Şanlı, 2007). Bronfenbrenner'ın Ekolojik Sistemler Kuramı'nın ilk halkası olan Mikrosistem doğrultusunda da çocuğun annesinin-babasının veya diğer aile bireylerinin çocuğa sağlıklı bilişsel gelişimi destekleyici davranışlar ve sosyal ve duygusal destek ve çabalar göstermesi, çocuğunda olumlu bilişsel, sosyal ve duygusal davranışlar sergilemesiyle paralel olduğu belirtilmektedir (Baydar, Küntay, Gökşen, Yağmurlu ve Cemalcılar, 2010). Bu çerçevede çocuğun ileriki dönemlerinde olumlu davranışlar sergilemesi, olumlu benlik saygısı kazanması, geleceğe yönelik amaç belirlemesi ve bu amaçlar doğrultusunda kararlar vermesi, problem çözme becerisini kullanması ve uyum ve işbirliği yeteneklerini kazanması ve kullanması gibi birçok yaşamsal önemi olan yetenek ve becerileri, ailenin çocuk yetiștirme stilleri ve tutumları ile yakından ilgilidir (Uyanık Balat, 2007; Arı, Bayhan ve Artan, 1997) .

Alan yazın incelendiğinde ebeveynlerin çocuk yetiştirirken davranışlarına yansıttığı birçok farklı tutum türüne rastlanmaktadır. Fakat genel olarak, ebeveynlerin çocuklarına 4 farklı tutum çerçevesinde davrandığı görülmektedir. Bu tutumlar, demokratik tutum, otoriter tutum, aşırı koruyucu tutum, izin verici tutumdur (Özben ve Argun, 2002).

Demokratik tutum, eşit ve paylaşımcı davranışların hâkim olduğu tutumdur. Anne babanın çocuğa sevgi ve bağımsızlık temellerinde yaklaşım sergiledikleri demokratik tutum içerisinde, çocuk evin bir bireyi olarak görülmekte ve hane içinde çocuğa da söz hakkı verilmektedir. Çocuğun yaşı ne olursa olsun onunda bir birey olduğu gerçeği bu tutum içerisinde vazgeçilmezdir. Bu sayede demokratik tutum içerisinde büyüyen çocuk cesaretle düşüncelerini anlatır ve bağımsız bir kişilik geliştirir (İnan Kızıltepe, Uyanık, Özsüer ve Can Yaşar, 2013). 
Otoriter tutum da ise ebeveynler çocukların düşüncelerini söylemesine ve tartışılmasına izin verilmeden çok sıkı bir şekilde kural ve emirlerin hâkim olduğu tutumdur. Bu tutumu sergileyen anne babalar çocuklarından kusursuz davranışlar sergilemesini beklemekte ve bu mükemmeliyet duygusu içerisinde beklendik davranış sergileyemeyen çocuk cezalandırılmaktadır. Aynı zamanda otoriter tutum kapsamında ebeveynler çocuklarının mutlak itaate uymas1, istek ve emirlere tartışmasız olarak yerine getirmesi istenir. Candan, samimi davranışların olmadığı otoriter tutumda çocuğun, kişilik ve yeteneklerini geliştirme olanaklarının azaldığı, benliğinin zedelendiği ve güven duygusunu yitirip kaygı düzeyinin $\operatorname{arttığı~belirlenmiştir~(Ulusoy,~Demir~ve~Baran,~2005).~Cenk-Sarı~ve~Demir~(2015)~tarafından~}$ ebeveynlerin çocuklarına karşı tutumları ile akademik başarı arasındaki ilişkiyi ortaya çıkartmaya çalıştıkları araştırmasında demokratik tutum sergileyen ebeveynlerin çocuklarının otoriter tutum sergileyen ebeveynlerin çocuklarına göre üst bir iyimserlik düzeyine sahip olduğu ve iyimserlik düzeyinin artmasının akademik başarıyı arttırdığı sonucuna ulaşılmıştır.

Bazı toplumlarda iyi çocuk yetiştirme tutumu olarak algılanan ve bu tutumdan dolayı ebeveynlerin övündüğü aşırı koruyucu tutumda, ebeveynler kollayıcı ve müdahaleci davranışlar sergilerler. Çocuğun o yaşta bağımsız olarak gerçekleştirmesi gereken birçok beceri ve yetenek ebeveynler tarafından yapılıp, çocuğa fırsatlar tanınmamaktadır. $\mathrm{Bu}$ tutumla yetiştirilen çocuklarda anne-babaya aşırı bağımlılık, güvensizlik, hayal kırıklığı ve istenmedik davranışlar, duygu kontrollerinde noksanlık, karar vermekte güçlük çekme durumu ve yetersiz sorumluluk duygusu gözlemlenmektedir (Y1lmaz, 2001).

İzin verici tutumda ise, ebeveynler aşırı kabul edici bir yaklaşımda çocuğunu yetiştirmektedirler. $\mathrm{Bu}$ nedenle bu tutumu benimseyen ebeveynlerin çocuk üzerindeki kontrolleri düşüktür. Aşırı derecede özgürlük veren izin verici tutuma sahip ebeveynler, çocuklarının tüm olaylarda kararlarının kendilerinin vermesinde sınır getirmezler. Bu tutum bazen ihmale varan hoşgörüye neden olmaktadır. Bu aşamada çocuk ailedeki insiyatif sahibi tek birey halini alır ve aile bireyleri çocuğun istek ve arzuları doğrultusunda kayıtsız ve şartsız kabul eden bir role girerler. $\mathrm{Bu}$ doğrultuda yetiştirilen çocukların ileriki yaşlarında sosyal becerilerinde ve sosyal uyumlarında problemler yaşadığı, eğitim öğretim yaşantısında karşısına gelen kurallarda hayal kırıklığına uğradığı, kendi dürtülerini kontrol edemediği ve bağımlı bir birey olduğu görülmektedir (Aksaray, 1992; Aksoy, Kılıç ve Kahraman, 2009).

$\mathrm{Bu}$ araştırmanın temel amacı, 48-72 aylık çocuğu olan anne ve babaların, çocuklarını yetiştirirken gösterdikleri ebeveynlik tutumlarının farklı bağımsız değişkenlere dayalı olarak incelenmesidir. Bu doğrultusunda araştırmanın ana problem cümlesi şu şekildedir: 
“48-72 ay arasında çocuğa sahip olan ebeveynlerin bazı değişkenlerine göre ebeveynlik tutumları farklılaşmakta mıdır?”

Ana problem cümlesi doğrultusundaki şu alt problemlere araştırmada cevaplar aranmıştır:

- Araştırmaya katılan ebeveynlerin ebeveynlik tutumları arasındaki yüzde frekans analizleri nasıldır?

- Araştırmaya katılan ebeveynlerin cinsiyet, çalışma durumu, aile yapısı, seminer alma durumu ve sahip oldukları çocuk cinsiyeti bağımsız değişkenleri ile ebeveyn tutumları arasında anlamlı bir farklılaşma var mıdır?

- Araştırmaya katılan ebeveynlerin yaş, öğrenim durumu, gelir düzeyi, çocuk sayısı ve çocukla geçirilen saat bağımsız değişkenleri ile ebeveyn tutumları arasında anlamlı bir farklılaşma var mıdır?

\section{YÖNTEM}

\section{Araştırmanın Modeli}

Bu çalışma nicel bir araştırma olup, tarama modeli kullanılarak bulgulara ulaşılmıştır. Tarama modeli, var olan bir durumu var olduğu şekliyle betimlemeyi amaçlayan araştırma yaklaşımıdır (Karasar, 2009). Araştırma, genel tarama modellerinden, betimsel tarama modeli ile hazırlanmıştır.

\section{Örneklem}

Araştırmanın çalışma grubunu, İstanbul ili Pendik ilçesinde 48-72 aylık çocuğu olan toplam 422 ebeveyn çalışma kapsamına alınmıştır. Katılımcılar seçilirken kolay ulaşılırlık ve gönüllülük esas alınmıştır. Katılımcılar ile ilgili demografik bilgiler Tablo 1'de verilmiştir.

Tablo 1. Katılımcıların Demografik Bilgileri

\begin{tabular}{|c|c|c|c|}
\hline Demografik Bilgiler & & $\mathbf{n}$ & $\%$ \\
\hline \multirow{3}{*}{ Cinsiyet } & Kadın & 303 & 71,8 \\
\hline & Erkek & 119 & 28,2 \\
\hline & Toplam & 422 & 100 \\
\hline \multirow{6}{*}{ Yaş } & $20-25$ yaş & 26 & 6,2 \\
\hline & $26-30$ yaş & 108 & 25,6 \\
\hline & 31-35 yaş & 123 & 29,1 \\
\hline & $36-40$ yaş & 102 & 24,2 \\
\hline & 41 yaş ve üstü & 63 & 14,9 \\
\hline & Toplam & 422 & 100 \\
\hline \multirow{5}{*}{ Öğrenim Durumu } & İlkokul & 42 & 10,0 \\
\hline & Ortaokul & 29 & 6,9 \\
\hline & Lise & 124 & 29,4 \\
\hline & Önlisans & 45 & 10,6 \\
\hline & Üniversite & 165 & 39,1 \\
\hline
\end{tabular}




\begin{tabular}{|c|c|c|c|}
\hline & Lisansüstü & 17 & 4,0 \\
\hline & Toplam & 422 & 100 \\
\hline \multirow{5}{*}{ Gelir Durumu } & $0-1000 \mathrm{tl}$ & 32 & 7,6 \\
\hline & $1001-2000 \mathrm{tl}$ & 103 & 24,4 \\
\hline & 2001-3000tl & 215 & 50,9 \\
\hline & 3001 tl ve üstü & 72 & 17,1 \\
\hline & Toplam & 422 & 100 \\
\hline \multirow{3}{*}{ Çalışma Durumu } & Çalışıyor & 275 & 65,2 \\
\hline & Çalışmıyor & 147 & 34,8 \\
\hline & Toplam & 422 & 100 \\
\hline \multirow{3}{*}{ Hane Yapısı } & Çekirdek Aile & 370 & 87,7 \\
\hline & Geniş Aile & 52 & 12,3 \\
\hline & Toplam & 422 & 100 \\
\hline \multirow{4}{*}{ Çocuk Sayısı } & 1 & 175 & 41,5 \\
\hline & 2 & 195 & 46,2 \\
\hline & 3 ve üzeri & 52 & 12,3 \\
\hline & Toplam & 422 & 100 \\
\hline \multirow{3}{*}{ Çocuk Cinsiyeti } & $\mathrm{K} 1 \mathrm{z}$ & 197 & 46,7 \\
\hline & Erkek & 225 & 53,3 \\
\hline & Toplam & 422 & 100 \\
\hline \multirow{7}{*}{ Çocukla İlgilenilen Ortalama Zaman } & $1-2$ saat & 45 & 10,6 \\
\hline & $3-4$ saat & 119 & 28,2 \\
\hline & $5-6$ saat & 118 & 28,0 \\
\hline & $7-8$ saat & 69 & 16,4 \\
\hline & 9-10 saat & 33 & 7,8 \\
\hline & 11 saat ve üstü & 38 & 9,0 \\
\hline & Toplam & 422 & 100 \\
\hline \multirow{3}{*}{ Çocuk Gelişimi İle İlgili Seminere Katılım Durumu } & Katıldım & 124 & 29,4 \\
\hline & Katılmadim & 298 & 70,6 \\
\hline & Toplam & 422 & 100 \\
\hline
\end{tabular}

Tablo 1 incelendiğinde, araştırma kapsamına alınan ebeveynlerin \%71,8'ini anneler ve \%28,2'sini ise babalar oluşturmaktadır. Bu bilgilere ek olarak katılımcıların \%29,1'inin 31-35 yaş arasında olduğu, \%39,1'inin üniversite mezunu olduğu, \%50,9'unun 2001-3000 tl aylık gelire sahip olduğu, \%65,2'sinin bir işte çalıştığı, \%87,7'sinin çekirdek bir aile yapısına sahip olduğu, \%46,2'sinin toplam 2 çocuk sahibi olduğu, \%53,3'ünün erkek çocuğuna sahip olduğu, \%28,2'sinin çocuğuyla 3-4 saat ilgilenebildiği ve \%70,6'sının çocuk gelişimi ile ilgili bir seminere katılmadığ tespit edilmiştir.

\section{Veri Toplama Araçları}

Araştırma kapsamında araştırmacı tarafından geliştirilen demografik bilgi formu ve Karabulut Demir ve Şendil (2008) tarafından geliştirilmiş “Ebeveyn Tutum Ölçeği”” kullanılmıştır.

\section{Demografik Bilgi Formu}

Demografik bilgi formu araştırmacı tarafından geliştirilmiş olup, ebeveynlerin demografik bilgilerini belirlemek amacıyla hazırlanmış toplam 10 sorudan oluşmaktadır. $\mathrm{Bu}$ formda ebeveynlerin cinsiyet, yaş, öğrenim durumu, gelir durumu, çalışma durumu, hane yapısı, çocuk 
sayısı, çocuk cinsiyeti, çocukla ilgilenilen süre ve çocuk gelişimi ile ilgili bir seminere katılma durumu tespit edilmeye çalışılmıştır.

\section{Ebeveyn Tutum Ölçeği}

Bu ölçek, Karabulut Demir ve Şendil (2008) tarafından geliştirilmiş olup, 2-6 yaş arasında çocuğu olan ebeveynlerin ebeveynlik tutumlarını belirlemek için kullanılmaktadır. Ölçek, ebeveynlerin demokratik tutumlarını (17 madde), otoriter tutumlarını (11 madde), aşırı koruyucu tutumlarını ( 9 madde) ve izin verici tutumlarını ( 9 madde) belirleyen dört alt boyuttan ve toplam 46 maddeden oluşmaktadır. Ebeveyn Tutum Ölçeği, beşli likert tipinde hazırlanmış olup, her bir maddenin karşısında sıklık ifadelerine yer verilmiştir. Bu sıklık maddeleri "her zaman böyledir", "çoğunlukla böyledir”, "bezen böyledir”, "nadiren böyledir” ve "hiçbir zaman böyle değildir" şeklindedir. Puanlamalar ise 1 ile 5 arasında verilmektedir. Ebeveynlerin ölçekteki her alt boyuttan aldıkları puanlar toplanarak, en yüksek aldıkları alt boyut hesaplanmaktadır. Ebeveyn hangi alt boyuttan en yüksek puanı almış ise, o alt boyuttaki ebeveyn tutumuna sahip olduğu sonucuna ulaşılır.

Yapılan bu araştırmada "Ebeveyn Tutum Ölçeği” güvenirlik analizi tekrardan yapılmış olup, cronbach alfa değerleri demokratik alt boyutta ,89, otoriter alt boyutta ,92, aşırı koruyucu alt boyutta , 88 ve izin verici alt boyutta ise, 83 olarak bulunmuştur.

\section{Veri Toplama Süreci}

Araştırma 2015-2016 eğitim öğretim yılı bahar yarıyılında gerçekleştirilmiştir. Araştırma için öncelikle Karabulut Demir ve Şendil (2008) tarafından geliştirilmiş Ebeveyn Tutum Ölçeği için yazılı izinler alınmıştır. Ardından Pendik İlçe Milli Eğitim Müdürlüğünden çalışma için izin yazıları yazılıp, ilçe kapsamındaki bağımsız anaokulları ve anasınıfları için gerekli izinler alınmıştır. Pendik ilçesinde kolay ulaşılabilirlik ilkesine uygun olarak 2 bağımsız anaokulu ve 8 ilköğretim okulu seçilmiş ve okul idarisi ile görüşülmüştür. Çalışmanın amacı okulun yöneticilerine, öğretmenlerine ve ailelerine sözel olarak anlatılmış olup, gerekli sözel izinler alınmıştır. Araştırmada kullanılacak ölçek çoğaltılarak, çocukların ebeveynlerine verilmiştir. Çalışmanın başlangıcında 500 ebeveyne ölçek verilmiştir. Araştırmacıya toplam 445 adet ölçek ulaştırılmıştır. Ebeveynlerden gelen ölçekler incelendiğinde eksik doldurulan 23 ölçek araştırma kapsamının dışına alınmıştır. Araştırmanın sonunda ebeveyn tarafından doldurulan toplam 422 ölçek araştırma kapsamında değerlendirilmiştir. 


\section{Verilerin Analizi}

Ölçekten toplanan veriler SPSS 21.0 programına girilmiştir. Öncelikle araştırmanın bağımsız değişkenleri için ayrı ayrı homojenlik ve normallik testleri yapılmış olup, verilerin her bağımsız değişken için homojen ve normallik koşullarını sağladığı tespit edilmiştir. Bu koşullar doğrultusunda araştırmada parametrik testlerden yararlanılmıştır. Veri analizi çerçevesinde yüzde, frekans, bağımsız t-testi ve tek yönlü varyans analizleri kullanılmıştır.

\section{BULGULAR}

48-72 aylık çocuğu olan anne ve babaların, çocuklarını yetiştirirken gösterdikleri ebeveynlik tutumlarının farklı bağımsız değişkenlere dayalı olarak incelenmesi amacıyla yapılan araştırma bulguları alt problemler doğrultusunda sırayla verilmiştir.

\section{Araştırmaya Katılan Ebeveynlerin Ebeveynlik Tutumları Arasındaki Yüzde Frekans}

\section{Analizleri Nasıldır?}

Uygulanan Ebeveyn Tutum Ölçeği verileri doğrultusunda araştırmaya katılan ebeveynlerin hangi tutumu daha yüksek oranda çocuğu için benimsedikleri belirlenmiş ve bulgular Tablo 2’de verilmiştir.

Tablo 2. Araştırmaya katılan anne ve babaların ebeveyn tutumları

\begin{tabular}{lll}
\hline Tutumlar & n & $\mathbf{\%}$ \\
\hline Demokratik Tutum & 354 & 83,9 \\
\hline Otoriter Tutum & 4 & 0,9 \\
\hline Așir1 Koruyucu Tutum & 38 & 9,0 \\
\hline İzin Verici Tutum & 26 & 6,2 \\
\hline Toplam & 422 & 100 \\
\hline
\end{tabular}

Tablo 2 incelendiğinde, araştırmaya katılan ebeveynlerin \%83,9'unun demokratik, \%9'unun aşırı koruyucu, \%6,2'sinin izin verici ve \%0,9'unun otoriter tutum puan ortalamalarının diğer tutum puan ortalamalarından yüksek olduğu belirlenmiştir. $\mathrm{Bu}$ doğrultuda araştırma kapsamındaki anne babaların yüksek oranda çocuklarına demokratik tutum doğrultusunda tutum sergilediği tespit edilmiştir.

Araştırmaya Katılan Ebeveynlerin Cinsiyet, Çalışma Durumu, Aile Yapısı, Seminer Alma Durumu ve Sahip Oldukları Çocuk Cinsiyeti Bağımsız Değişkenleri İle Ebeveyn Tutumları Arasında Anlamlı Bir Farklılaşma Var mıdır?

Anne ve babaların Ebeveyn Tutum Ölçeğinden almış oldukları puanlar ile ebeveynlerin cinsiyet, çalışma durumu, aile yapısı, seminer alma durumu ve sahip oldukları çocuk cinsiyeti bağımsız değişkenleri arasında anlamlı bir farklılaşmanın olup olmadığını tespit etmek 
amacıyla bağımsız t-testi uygulanmıştır. Uygulanan bağımsız t-testi sonuçları tablo 3 'te verilmiştir.

Tablo 3. Ebeveynlerin cinsiyet, çalışma durumu, aile yapısı, seminer alma durumu ve çocuklarının cinsiyeti bă̆ımsız değişkenleri ile ebeveyn tutumları arasındaki bağımsız t-testi sonuçları

\begin{tabular}{|c|c|c|c|c|c|c|}
\hline Tutumlar & Ebeveyn Türü & $\mathbf{n}$ & $\mathbf{X}$ & ss & $\mathbf{t}$ & $\mathbf{p}$ \\
\hline \multirow{2}{*}{ Demokratik } & Anne & 303 & 3,902 & ,374 & \multirow{2}{*}{1,040} & \multirow{2}{*}{,299 } \\
\hline & Baba & 119 & 3,859 & ,393 & & \\
\hline \multirow{2}{*}{ Otoriter } & Anne & 303 & 2,492 & 461 & \multirow{2}{*}{,755 } & \multirow{2}{*}{, 451} \\
\hline & Baba & 119 & 2,454 &, 502 & & \\
\hline \multirow{2}{*}{ Aşırı Koruyucu } & Anne & 303 & 3,303 & ,481 & \multirow{2}{*}{1,817} & \multirow{2}{*}{, 071} \\
\hline & Baba & 119 & 3,212 & ,457 & & \\
\hline \multirow{3}{*}{ İzin Verici } & Anne & 303 & 2,976 & ,489 & \multirow{2}{*}{$-1,476$} & \multirow{2}{*}{, 141} \\
\hline & Baba & 119 & 3,054 & 481 & & \\
\hline & Çalışma Durumu & $\mathbf{n}$ & $\mathbf{X}$ & ss & $\mathbf{t}$ & $\mathbf{p}$ \\
\hline \multirow{2}{*}{ Demokratik } & Çalıșıyor & 275 & 3,869 &, 355 & \multirow{2}{*}{$-1,537$} & \multirow{2}{*}{, 125} \\
\hline & Çalışmıyor & 147 & 3,929 & 419 & & \\
\hline \multirow{2}{*}{ Otoriter } & Çalışıyor & 275 & 2,458 & ,465 & \multirow{2}{*}{$-1,413$} & \multirow{2}{*}{, 158} \\
\hline & Çalışmıyor & 147 & 2,526 & ,484 & & \\
\hline \multirow{2}{*}{ Aşırı Koruyucu } & Çalışıyor & 275 & 3,225 & ,457 & \multirow{2}{*}{$-3,036$} & \multirow{2}{*}{, $003 *$} \\
\hline & Çalıșmıyor & 147 & 3,375 & 496 & & \\
\hline \multirow{3}{*}{ İzin Verici } & Çalışıyor & 275 & 3,008 & 466 & \multirow{2}{*}{,591 } & \\
\hline & Çalışmıyor & 147 & 2,979 &, 527 & & ,555 \\
\hline & Aile Yapısı & $\mathbf{n}$ & $\mathbf{X}$ & ss & t & $\mathbf{p}$ \\
\hline Demokratik & Çekirdek Aile & 370 & 3,892 & ,363 & 170 & 832 \\
\hline DemokratıK & Geniş Aile & 52 & 3,880 &, 486 & , 170 & , 832 \\
\hline Otoriter & Çekirdek Aile & 370 & 2,470 & ,459 & -1269 & 205 \\
\hline Otoriter & Geniş Aile & 52 & 2,559 & ,564 & $-1,269$ & 205 \\
\hline A sur 1 Koruyusu & Çekirdek Aile & 370 & 3,270 & ,477 & -965 & 335 \\
\hline Aşırı Koruyucu & Geniş Aile & 52 & 3,338 & 473 &,- 963 & ,335 \\
\hline İzin Verici & Çekirdek Aile & 370 & 2,993 & 495 & & \\
\hline Izin Veric1 & Geniş Aile & 52 & 3,043 & 431 &,- 688 &, 492 \\
\hline & Seminere Katılım & $\mathbf{n}$ & $\mathbf{X}$ & ss & t & $\mathbf{p}$ \\
\hline Demokratik & Katıldım & 124 & 3,846 & ,355 & 1531 & 127 \\
\hline DemokratıK & Katılmadım & 298 & 3,908 &, 388 & $-1,531$ &, 121 \\
\hline Otoriter & Katıldım & 124 & 2,415 &, 395 & -2048 & $041 *$ \\
\hline Otoriter & Katılmadım & 298 & 2,509 & 499 & $-2,048$ & ,041* \\
\hline Asurı Korumusu & Katıldım & 124 & 3,134 & ,438 & -4075 & $001 *$ \\
\hline 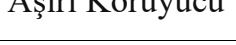 & Katılmadım & 298 & 3,337 & ,479 & $-4,0 / 3$ & , \\
\hline İzin Verici & Katıldım & 124 & 2,933 &, 462 & 1772 & 077 \\
\hline IZIn vericl & Katılmadım & 298 & 3,025 & ,496 & $-1, / / 2$ & , \\
\hline & Çocuğun Cinsiyeti & $\mathrm{n}$ & $\mathbf{X}$ & ss & t & $\mathbf{p}$ \\
\hline Demokratik & Kiz & 197 & 3,895 &, 365 & 266 & 791 \\
\hline Demokratik & Erkek & 225 & 3,885 &, 392 & , 206 &, 191 \\
\hline Otoriter & $\mathrm{K} 1 \mathrm{z}$ & 197 & 2,400 &, 449 & -3.357 & $001 *$ \\
\hline Utoriter & Erkek & 225 & 2,553 & 482 & $-3,35 /$ & ,001* \\
\hline A ser Koruyucu & Kız & 197 & 3,316 &, 475 & 1537 & 125 \\
\hline Aşırı Kortuyucu & Erkek & 225 & 3,244 & ,474 & 1,531 &, 125 \\
\hline İzin Verici & Kiz & 197 & 2,969 & ,483 & -1167 & 244 \\
\hline IZIn verici & Erkek & 225 & 3,024 & 491 & $-1,10 /$ &, 244 \\
\hline
\end{tabular}

Tablo 3 incelendiğinde, tutum puan ortalamaları ile ebeveynin cinsiyet ve aile yapısı bağımsız değişkenleri arasında anlamlı bir farklılaşmanın olmadığı sonucuna ulaşılmıştır. Bunun yanı sıra, ebeveynin çalışma durumu bağımsız değişkeni ile aşırı koruyucu tutum puanları arasında 
anlamlı bir farklılaşma tespit edilmiştir. Farklılaşma çalışan ebeveynlerin lehinedir. Bir başka ifadeyle, çalışmayan ebeveynler, çalışan ebeveynlere göre anlamlı oranda çocuğuna karşı daha aşırı koruyucu bir tutum sergilediği görülmüştür. Ebeveynlerin seminere katılma durumu bağımsız değişkeni ile otoriter ve aşırı koruyucu tutum puan ortalamaları arasında anlamlı bir farklılaşmaya rastlanmaktadır. Seminere katılmayan ebeveynlerin otoriter ve aşırı koruyucu tutum puan ortalamaları, seminere katılan ebeveynlerin puan ortalamalarına oranla daha yüksek olduğu görülmektedir. Bir diğer deyişle, seminere katılmayan ebeveynler, seminere katılan ebeveynlere oranla çocuğuna daha çok otoriter ve aşırı koruyucu tutum içinde olduğu bir davranış sergilediği sonucuna ulaşılmıştır. Son olarak ebeveynlerin sahip oldukları çocuk cinsiyeti bağımsız değişkeni ile otoriter tutum puan ortalamaları arasında anlamlı bir farklılaşma olduğu belirlenmiştir. Erkek çocuğa sahip ebeveynlerin, kız çocuğa sahip olan ebeveynlere oranla daha otoriter bir tutum içinde olduğu sonucuna ulaşılmıştır.

\section{Araştırmaya Katılan Ebeveynlerin Yaş, Öğrenim Durumu, Gelir Düzeyi, Çocuk Sayısı ve} Çocukla Geçirilen Saat Bağımsız Değişkenleri İle Ebeveyn Tutumları Arasında Anlamlı

\section{Bir Farklılaşma Var mıdır?}

Üçüncü alt problem çerçevesinde araştırmaya katılan ebeveynlerin yaş, öğrenim durumu, gelir düzeyi, çocuk sayısı ve çocukla geçirilen saat bağımsız değişkenleri ile ebeveyn tutum ölçeği kapsamındaki demokratik, otoriter, aşırı koruyucu ve izin verici tutum alt boyutları ayrı ayrı incelenmiş olup, verilerin analizinde tek yönlü varyans analizi (ANOVA) kullanılmıştır. ANOVA sonuçları Tablo 4-5-6-7'de verilmiştir.

Tablo 4. Ebeveynlerin yaş, öğrenim, gelir, çocuk sayısı ve çocukla geçirilen zaman değişkeni ile demokratik tutum puan ortalamaları arasında yapılan tek yönlü varyans analizi sonuçları

\begin{tabular}{|c|c|c|c|c|c|c|c|}
\hline & & $\begin{array}{l}\text { Varyans } \\
\text { Kaynağı }\end{array}$ & $\begin{array}{l}\text { Kareler } \\
\text { Toplamı }\end{array}$ & sd & $\begin{array}{l}\text { Kareler } \\
\text { Ortalaması }\end{array}$ & $\mathbf{F}$ & p \\
\hline \multirow{15}{*}{ 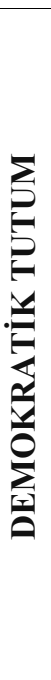 } & \multirow{3}{*}{$\stackrel{\pi}{\star}$} & Gruplararası & 1,789 & 4 &, 447 & \multirow{3}{*}{3,167} & \multirow{3}{*}{, $014^{*}$} \\
\hline & & Gruplariçi & 58,894 & 417 & ,141 & & \\
\hline & & Toplam & 60,684 & 421 & & & \\
\hline & \multirow{3}{*}{ 苞 } & Gruplararası & 1,454 & 5 & ,291 & \multirow{3}{*}{2,043} & \multirow{3}{*}{,072 } \\
\hline & & Gruplariçi & 59,229 & 416 & , 142 & & \\
\hline & & Toplam & 60,684 & 421 & & & \\
\hline & \multirow{3}{*}{ : } & Gruplararası & 079 & 3 & ,026 & \multirow{3}{*}{, 182} & \multirow{3}{*}{,909 } \\
\hline & & Gruplariçi & 60,605 & 418 & , 145 & & \\
\hline & & Toplam & 60,684 & 421 & & & \\
\hline & \multirow{3}{*}{ 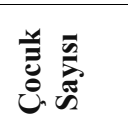 } & Gruplararası & 177 & 2 & ,089 & \multirow{3}{*}{,614 } & \multirow{3}{*}{, 542} \\
\hline & & Gruplariçi & 60,506 & 419 & , 144 & & \\
\hline & & Toplam & 60,684 & 421 & & & \\
\hline & \multirow{3}{*}{ 产 兽 } & Gruplararası & 1,092 & 5 & ,218 & \multirow{3}{*}{1,525} & \multirow{3}{*}{, 181} \\
\hline & & Gruplariçi & 59,592 & 416 & ,143 & & \\
\hline & & Toplam & 60,684 & 421 & & & \\
\hline
\end{tabular}


Tablo 4'e göre, ebeveynlerin demokratik tutum puan ortalamaları ile yaş bağımsız değişkeni arasında anlamlı bir farklılaşmanın olduğu tespit edilmiştir [F(4-417) $=3,167 ; p<0.05]$. Yapılan Tukey testi sonucunda, bu farklılaşmanın 20-25 yaş ebeveynler ile 26-30/31-35 ve 36-40 yaş ebeveynler arasında olduğu sonucuna ulaşılmıştır. Bir başka anlatımla, 26-30/31-35 ve 36-40 yaş ebeveynlerinin, 20-25 yaş ebeveynlerine göre çocuk yetiştirirken demokratik tutumu daha çok benimsediği görülmektedir. Demokratik tutum puan ortalamaları ile karşılaştırılan öğrenim, gelir, çocuk sayısı ve çocukla geçirilen saat gibi diğer bağımsız değişkenlerle anlamlı bir farklılaşmanın olmadığ sonucuna ulaşılmıştır.

Tablo 5. Ebeveynlerin yaş, öğrenim, gelir, çocuk saylsı ve çocukla geçirilen zaman değişkeni ile otoriter tutum puan ortalamaları arasında yapılan tek yönlü varyans analizi sonuçları

\begin{tabular}{|c|c|c|c|c|c|c|c|}
\hline & & $\begin{array}{l}\text { Varyans } \\
\text { Kaynağı }\end{array}$ & $\begin{array}{l}\text { Kareler } \\
\text { Toplamı }\end{array}$ & sd & $\begin{array}{l}\text { Kareler } \\
\text { Ortalaması }\end{array}$ & $\mathbf{F}$ & $\mathbf{p}$ \\
\hline \multirow{15}{*}{ 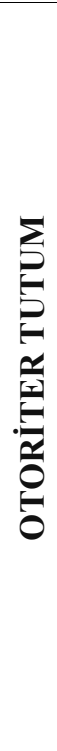 } & \multirow{3}{*}{ 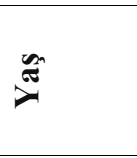 } & Gruplararası & 1,106 & 4 & ,276 & \multirow{3}{*}{1,238} & \multirow{3}{*}{,294 } \\
\hline & & Gruplariçi & 93,074 & 417 & ,223 & & \\
\hline & & Toplam & 94,179 & 421 & & & \\
\hline & \multirow{3}{*}{ 0 } & Gruplararası & ,930 & 5 &, 186 & \multirow{3}{*}{, 830} & \multirow{3}{*}{, 529} \\
\hline & & Gruplariçi & 93,249 & 416 &, 224 & & \\
\hline & & Toplam & 94,179 & 421 & & & \\
\hline & \multirow{3}{*}{ : } & Gruplararası & 1,366 & 3 & ,455 & \multirow{3}{*}{2,051} & \multirow{3}{*}{,106 } \\
\hline & & Gruplariçi & 92,813 & 418 &, 222 & & \\
\hline & & Toplam & 94,179 & 421 & & & \\
\hline & \multirow{3}{*}{ 光 } & Gruplararas1 & 2,103 & 2 & 1,051 & \multirow{3}{*}{4,784} & \multirow{3}{*}{, $009 *$} \\
\hline & & Gruplariçi & 92,077 & 419 & ,220 & & \\
\hline & & Toplam & 94,179 & 421 & & & \\
\hline & \multirow{3}{*}{ 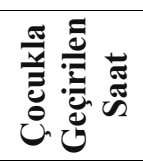 } & Gruplararası &, 322 & 5 &, 064 & \multirow{3}{*}{, 285} & \multirow{3}{*}{,921 } \\
\hline & & Gruplariçi & 93,858 & 416 & ,226 & & \\
\hline & & Toplam & 94,179 & 421 & & & \\
\hline
\end{tabular}

$*_{\mathrm{p}}<.05$

Tablo 5 incelendiğinde, ebeveynlerin otoriter tutum puan ortalamaları ile sahip oldukları çocuk sayısı bağımsız değişkeni arasında anlamlı bir farklılaşmanın olduğu tespit edilmiştir[F(2419) $=4,784 ; \mathrm{p}<0.01]$. Yapılan Tukey testi sonucunda, bu farklılaşmanın tek çocuk sahibi olan ebeveynler ile üç ve daha fazla çocuğa sahip olan ebeveynler arasında olduğu bulunmuştur. Farklılaşma tek çocuk sahibi olan ebeveynlerin lehinedir. Bir başka deyişle, tek çocuk sahibi olan ebeveynler, üç ve daha fazla çocuğa sahip ebeveynlere oranla çocuklarına daha az otoriter tutum sergilemektedir. Ebeveynlerin yaş, öğrenim, gelir ve çocukla geçirilen saat bağımsız değişkeni ile otoriter tutum puan ortalamaları arasında anlamlı bir farklılaşmaya rastlanmamıştır. 
Tablo 6. Ebeveynlerin yaş, öğrenim, gelir, çocuk sayısı ve çocukla geçirilen zaman değişkeni ile aşırı koruyucu tutum puan ortalamaları arasında yapılan tek yönlü varyans analizi sonuçları

\begin{tabular}{|c|c|c|c|c|c|c|c|}
\hline & & $\begin{array}{l}\text { Varyans } \\
\text { Kaynağı }\end{array}$ & $\begin{array}{l}\text { Kareler } \\
\text { Toplamı }\end{array}$ & sd & $\begin{array}{l}\text { Kareler } \\
\text { Ortalaması }\end{array}$ & $\mathbf{F}$ & $\mathbf{p}$ \\
\hline \multirow{15}{*}{ 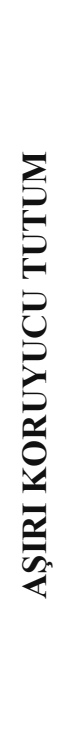 } & \multirow{3}{*}{ 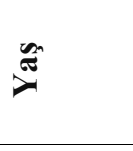 } & Gruplararası & 1,044 & 4 & ,261 & \multirow{3}{*}{1,153} & \multirow{3}{*}{, 331} \\
\hline & & Gruplariçi & 94,382 & 417 & ,226 & & \\
\hline & & Toplam & 95,426 & 421 & & & \\
\hline & \multirow{3}{*}{ 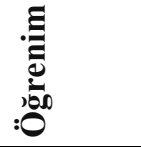 } & Gruplararası & 4,449 & 5 & 890 & \multirow{3}{*}{4,069} & \multirow{3}{*}{, $001 *$} \\
\hline & & Gruplariçi & 90,976 & 416 & ,219 & & \\
\hline & & Toplam & 95,426 & 421 & & & \\
\hline & \multirow{3}{*}{ שֶ } & Gruplararası & 2,144 & 3 & ,715 & \multirow{3}{*}{3,203} & \multirow{3}{*}{, $023^{*}$} \\
\hline & & Gruplariçi & 93,281 & 418 & 223 & & \\
\hline & & Toplam & 95,426 & 421 & & & \\
\hline & \multirow{3}{*}{ 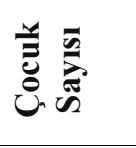 } & Gruplararası & ,106 & 2 & ,053 & \multirow{3}{*}{,234 } & \multirow{3}{*}{, 792} \\
\hline & & Gruplariçi & 95,319 & 419 & 227 & & \\
\hline & & Toplam & 95,426 & 421 & & & \\
\hline & \multirow{3}{*}{ 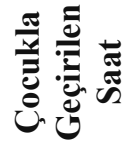 } & Gruplararası & 1,964 & 5 & ,393 & \multirow{3}{*}{1,748} & \multirow{3}{*}{,122 } \\
\hline & & Gruplariçi & 93,462 & 416 & 225 & & \\
\hline & & Toplam & 95,426 & 421 & & & \\
\hline
\end{tabular}

Tablo 6 incelendiğinde, araştırmaya katılan ebeveynlerin öğrenim $[F(5-416)=4,069 ; p<0.05]$ ve gelir durumu $[\mathrm{F}(3-418)=3,203 ; \mathrm{p}<0.05]$ bağımsız değişkeni ile aşırı koruyucu tutum puan ortalamaları arasında anlamlı bir farklılaşma olduğu görülmektedir. Öğrenim durumu değişkeni arasındaki farklılaşmanın hangi gruplar arasında olduğunu belirlemek amacıyla yapılan Tukey testi sonuçları doğrultusunda, lisansüstü mezunu ebeveynler ile ilkokul ve önlisans mezunu ebeveynler arasında bir farklılaşmanın olduğu tespit edilmiştir. Farklılaşma lisansüstü mezunu ebeveynler lehinedir. Bir diğer anlatımla, lisansüstü mezunu ebeveynlerin, ilkokul ve önlisans mezunu ebeveynlere oranla daha az aşırı koruyucu tutum içinde çocuğuna davranış sergilediği sonucuna ulaşılmıştır. Gelir durumu değişkenleri arasındaki farklılaşmanın hangi gruplar arasında olduğunu belirlemek amacıyla yapılan Tukey testi sonuçlarında ise, farklılaşmanın 01000 tl gelir durumuna sahip ebeveynler ile $3001 \mathrm{tl}$ ve üzeri gelir durumuna sahip ebeveynler arasında olduğu sonucuna ulaşılmıştır. Farklılaşma 3001 tl ve üzeri gelir durumuna sahip ebeveynler lehinedir. Bir diğer anlatımla, 0-1000 tl gelir durumuna sahip ebeveynler, $3001 \mathrm{tl}$ ve üzeri gelir durumuna sahip ebeveynlere oranla çocuklarına aşırı koruyucu tutum sergilediği tespit edilmiştir. Ebeveynlerin yaş, çocuk sayısı ve çocukla geçirilen saat bağımsız değişkenleri ile aşırı koruyucu tutum puan ortalamaları arasında anlamlı bir farklılaşmanın olmadığı bulunmuştur. 
Tablo 7. Ebeveynlerin yaş, ögrenim, gelir, çocuk sayısı ve çocukla geçirilen zaman değişkeni ile izin verici tutum puan ortalamaları arasında yapılan tek yönlü varyans analizi sonuçları

\begin{tabular}{|c|c|c|c|c|c|c|c|}
\hline & & $\begin{array}{l}\text { Varyans } \\
\text { Kaynağı }\end{array}$ & $\begin{array}{l}\text { Kareler } \\
\text { Toplamı }\end{array}$ & sd & $\begin{array}{l}\text { Kareler } \\
\text { Ortalamas! }\end{array}$ & $\mathbf{F}$ & $\mathbf{p}$ \\
\hline \multirow{15}{*}{ 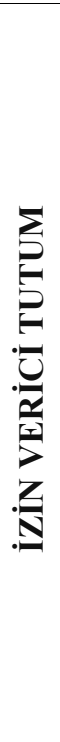 } & \multirow{3}{*}{ 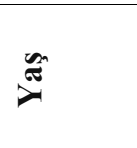 } & Gruplararas1 & 2,208 & 4 & ,552 & \multirow{3}{*}{2,347} & \multirow{3}{*}{,054 } \\
\hline & & Gruplariçi & 98,077 & 417 & ,235 & & \\
\hline & & Toplam & 100,285 & 421 & & & \\
\hline & \multirow{3}{*}{ סू: } & Gruplararas1 & ,342 & 5 & ,068 & \multirow{3}{*}{,285 } & \multirow{3}{*}{,921 } \\
\hline & & Gruplariçi & 99,943 & 416 & , 240 & & \\
\hline & & Toplam & 100,285 & 421 & & & \\
\hline & \multirow{3}{*}{ 离 } & Gruplararas1 & 2,049 & 3 & ,683 & \multirow{3}{*}{2,907} & \multirow{3}{*}{,055 } \\
\hline & & Gruplariçi & 98,235 & 418 & ,235 & & \\
\hline & & Toplam & 100,285 & 421 & & & \\
\hline & \multirow{3}{*}{ 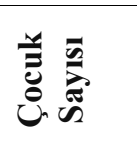 } & Gruplararas1 & 2,904 & 2 & 1,452 & \multirow{3}{*}{6,247} & \multirow{3}{*}{, $002 *$} \\
\hline & & Gruplariçi & 97,381 & 419 & 232 & & \\
\hline & & Toplam & 100,285 & 421 & & & \\
\hline & \multirow{3}{*}{ 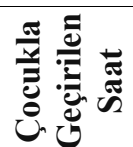 } & Gruplararas1 & ,495 & 5 & ,099 & \multirow{3}{*}{,413 } & \multirow{3}{*}{, 840} \\
\hline & & Gruplariçi & 99,790 & 416 & , 240 & & \\
\hline & & Toplam & 100,285 & 421 & & & \\
\hline
\end{tabular}

Tablo 7 incelendiğinde, araştırmaya katılan ebeveynlerin çocuk sayısı bağımsız değişkeni ile izin verici tutum puan ortalamaları arasında anlamlı derecede farklılaşma olduğu görülmektedir $[\mathrm{F}(2-419)=6,247 ; \mathrm{p}<0.01]$. Çocuk sayısı değişkeni arasındaki farklılaşmanın hangi yönde olduğunu belirlemek amacıyla yapılan Tukey testi sonuçları doğrultusunda, iki çocuk sahibi ebeveynler ile üç ve üzeri çocuk sahibi ebeveynler arasında bir farklılaşmanın olduğu tespit edilmiştir. Farklılaşma iki çocuk sahibi ebeveynler lehinedir. Bir diğer anlatımla, iki çocuk sahibi ebeveynlerin, üç ve üzeri çocuğa sahip ebeveynlere oranla daha az izin verici tutum içinde olduğu sonucuna ulaşılmıştır. Ebeveynlerin yaş, öğrenim, gelir durumu ve çocukla geçirilen saat bağımsız değişkenleri ile izin verici tutum puan ortalamaları arasında anlamlı bir farklılaşmanın olmadığı görülmüştür.

\section{SONUÇ ve TARTIŞMA}

48-72 aylık çocuğu olan anne ve babaların, çocuklarını yetiştirirken gösterdikleri ebeveynlik tutumlarının farklı bağımsız değişkenlere dayalı olarak incelenmesi amacıyla yapılan çalışma bulgularının ilki, araştırmaya katılan 422 ebeveynin büyük bir kısmının $(\% 83,9)$ çocuğuna demokratik tutum içinde yaklaşım sergilediği yönündedir. Geri kalan ebeveynlerin \%9'unun aşırı koruyucu, \%6,2'sinin izin verici ve \%0,9'unun ise otoriter tutum ile çocuğa yaklaşım sergilediği sonucuna ulaşılmıştır. Durmuşoğlu Saltalı ve Arslan (2012) tarafından yapılan çalışmada da Ebeveynlik Tutum Ölçeği (ETÖ) kullanılmış olup, ebeveynlerin tutum ölçeği alt boyutlarından demokratik tutum puanlarından en yüksek ortalamayı aldığı tespit edilmiştir. $\mathrm{Bu}$ 
bulgu araştırma ile paralellik göstermektedir. Aynı zamanda ebeveynlerin büyük çoğunluğunun demokratik tutum içinde olmasının bir diğer nedeni ise çalışmaya katılan katılımcıların şehir merkezinde yaşamasından kaynaklı olduğu düşünülebilir. İnal Kızıltepe, Uyanık, Özsüzer ve Can Yaşar'ın (2013) 61-72 aylık çocukların demokratik tutum ve davranışlarının anne görüşlerine göre değerlendirilmesi amacıyla gerçekleştirdikleri çalışmada da şehir merkezindeki okul öncesi eğitim kurumlarına devam eden çocukların ebeveynleri, merkeze bağlı köylerde yaşayan ebeveynlere oranla daha demokratik tutum ve davranış sergiledikleri sonucuna ulaşılmıştır. İkinci derece de aşırı koruyucu ebeveyn tutumunun çıkması ise geleneksel Türk aile yapısı ile ilişkili olduğu söylenebilir. Geleneksel Türk toplumunda ebeveynler çocuklarının yapabilecekleri görevleri bile üstlenmektedir. Bu tutum sonucunda çocukların problem çözme becerileri, karar alma becerileri ve sorumluluk becerileri engellenmektedir (Yavuzer, 1999; Poyraz ve Özyürek, 2005).

Ayrıca çalışma bulguları doğrultusunda, çalışmayan ebeveynler, çalışan ebeveynlere göre anlamlı oranda çocuğuna daha aşırı koruyucu bir tutum içinde davranış sergilediği görülmüştür. Tortumoğlu (1999) çalışmasında da çalışan ve çalışmayan annelerin aşırı koruyucu tutumlarını karşılaştırmış ve sonuç olarak çalışmayan annelerin çocuklarıyla daha fazla zaman geçirmeleri nedeniyle çocuklarına karşı daha koruyucu bir tutum içinde yaklaştığı sonucuna ulaşmışlardır. Ayyıldız (2005), Ömeroğlu (1996) ve Şanlı (2007) çalışmalarında da çalışmayan annelerin çalışan annelere oranla daha aşırı koruyucu bir çocuk yetiştirme biçimini sergilediği sonucuna ulaşılmıştır. Ek olarak çocuk gelişimi ile ilgili bir seminere katılmayan ebeveynler, seminere katılan ebeveynlere oranla çocuğuna daha çok otoriter ve aşırı koruyucu tutum doğrultusunda bir davranış sergilediği sonucuna ulaşılmıştır. Yılmaz Bolat (2011) tarafindan yapılan çalışmada da ebeveynlerin ihtiyaçları doğrultusunda verilecek olan eğitimin ebeveynlerin doğru tutumlarla çocuklarını yetiştirebileceğini belirtmiştir. Toplamda 50 anne ve babayı araştırmasına dahil ettiği deneysel çalışmasında, çocuk yetiştirme tutum ve davranışlarına yönelik 12 haftalık bir eğitim programı düzenlemiştir. Program sonucunda anne babaların son test puanlarının ön test puanlarından anlamlı derecede farklılaştığı sonucuna ulaşılmıştır. $\mathrm{Bu}$ doğrultuda ebeveynlere verilen seminer veya eğitimler ailelerin çocuk yetiştirme tutum ve davranışlarını olumlu yönde etkilemektedir. Ayrıca erkek çocuğuna sahip ebeveynlerin, kız çocuğuna sahip olan ebeveynlere oranla daha çok otoriter tutum çerçevesinde bir davranış içinde olduğu sonucuna ulaşılmıştır. Von Der Lippe (1999) tarafindan yapılan çalışmada öğrenim düzeyi düşük olan ebeveynlerin erkek çocukların daha yüksek oranda kontrol uygulandığını saptamış, hatta erkek çocuklarına gerektiğinde fiziksel ceza uygulanması 
yapılabileceğine inandıklarını belirlemiştir. Mızrakçı (1994) kız çocuklarının ise aileleri tarafından koruyucu tutum sergilediği sonucuna ulaşmıştır. Bu araştırmada da kız çocuklarının, erkek çocuklarına oranla aşırı koruyucu puan ortalamalarının daha yüksek olduğu fakat anlamlı bir şekilde farklılaşmadığı saptanmıştır. Ayrıca Kapıkıran, İvrendi ve Adak’ın (2005) yılında okul öncesi çocuklarında sosyal becerileri üzerine gerçekleştirdikleri durum çalışması sonucunda da ebeveynlerin çocuk yetiştirmede erkek ve kız çocuklarına ebeveynler tarafından farklı tutum sergilendiği ve bu tutum farklılaşmalarından dolayı çocukların sosyal becerilerinin etkilendiği sonucuna ulaşılmıştır. Ebeveynlerin kız ve erkek çocuklarına farklı tutum sergilemesinin nedenlerinden birisinin erkek ve kız çocuklarının davranış farklılıklarından olduğu söylenebilir. Özbey ve Alisinanoğlu'nun (2009) okul öncesi eğitim kurumlarına devam eden 60-72 aylık çocukların problem davranışlarının belirlenmesi amacıyla gerçekleştirdikleri araştırma sonucunda da erkek çocuklarının kız çocuklarına gore problem davranış ölçeğinin anti sosyal ve dişa yönelim alt boyut puanlarının daha yüksek olduğu sonucuna ulaşılmıştır. Bir diğer ifade ile kız çocuklarının erkek çocuklara oranla, daha az problem davranışa sahip oldukları görülmüsştür. Bu davranış problemlerinden kaynaklı ebeveynler erkek çocuklarına daha otoriter tutum sergilediği düşünülebilir.

Araştırma kapsamında 26-30/31-35 ve 36-40 yaş ebeveynlerinin, 20-25 yaş ebeveynlerine göre çocuk yetiştirirken demokratik tutumu daha çok davranışına yansıttığı sonucuna ulaşılmıştır. Ayyıldız (2005), Mızrakçı (1994) ve Grigorenko ve Sternberg (2000) yaptıkları araştırma sonuçlarında da ebeveynlerin çocuk sahibi olma yaşının ebeveyn-çocuk arasındaki davranışı etkilediği sonucuna ulaşmışlardır. $\mathrm{Bu}$ sonuçlar çalışmanın bulgularıyla paralellik göstermektedir. Özellikle genç yaştaki anne babaların ilk çocuğu olduğu ve ilk çocuktan beklentisi yüksek olduğu için demokratik tutum yerine aşırı koruyucu tutum çerçevesinde davranış sergilediği söylenebilir. Ayrıca tek çocuk sahibi olan ebeveynler, üç ve daha fazla çocuğa sahip ebeveynlere oranla çocuklarına daha az otoriter tutum içinde davranış sergilemektedir. Araştırmada ek olarak ebeveynlerin öğrenim durumları ile aşırı koruyucu tutum puan ortalamaları arasında anlamlı bir farklılaşmaya rastlanmıştır. Lisansüstü mezunu ebeveynlerin, ilkokul ve önlisans mezunu ebeveynlere oranla daha az aşırı koruyucu tutum içinde çocuğuna davranış sergilediği sonucuna ulaşılmıştır. Karabulut Demir ve Şendil (2008) ve Mızrakçı (1994) tarafından yapılan çalışmada da ebeveynlerin öğrenim düzeyi arttıkça daha istendik bir tutum içinde bir davranış sergilediğini tespit etmişlerdir. Bu sonuç çalışmanın sonucu ile paralellik göstermektedir. Aynı zamanda aşırı koruyucu tutumlar ile ailenin gelir durumu arasında anlamlı bir farklılaşma görülmüştür. 0-1000 tl gelir durumuna sahip 
ebeveynler, 3001 tl ve üzeri gelir durumuna sahip ebeveynlere oranla çocuklarına aşırı koruyucu tutum doğrultusunda davranış sergilediği tespit edilmiştir. Alpoğuz (2014) tarafından ilköğretim öğrencilerinin algıladıkları anne baba tutumlarının aile gelir durumu ile ilişkisini araştırdıkları çalışmasında da gelir düzeyi arttıkça çocukların anne-baba tutumlarının farklılaştığı saptanmıştır. Gelir düzeyi arttıkça öğrencilerin algıladıkları anne baba tutumları daha demokratik olurken, gelir düzeyi düştükçe ise otoriter algıladıkları sonucuna ulaşılmıştır. Ömeroğlu (1996), Şanlı (2007) ve Ayyıldız (2005) yaptıkları çalışmalarında da gelir durumu aile tutumları ile farklılaşmakta olduğu sonucuna ulaşmıştır. Bu sonuçlar araştırmanın bulguları ile paralellik göstermektedir. Araştırmada son olarak iki çocuk sahibi ebeveynlerin, üç ve üzeri çocuğa sahip ebeveynlere oranla daha az izin verici tutum içinde çocuğuna davranış sergilediği sonucuna ulaşılmıştır.

Okul öncesi dönem çocuğu olan ebeveynlerin, çocuklarını yetiştirirken gösterdikleri ebeveynlik tutumlarının farklı bağımsız değişkenlere dayalı olarak incelenmesi amacıyla yapılan çalışmanın bulguları doğrultusunda şu önerilerde bulunulabilir:

- Ebeveyn tutumları ile ilgili olarak üniversiteler, belediyeler ve sivil toplum kuruluşları ortaklaşa olarak projeler çerçevesinde ücretsiz ebeveynlere seminerler, kurslar veya workshoplar düzenlenebilir.

- Ebeveyn tutumları ile ilgili olarak düzenli bültenler hazırlanıp sosyoekonomik düzeyi düşük bölgelerde dağıtılabilir.

- Okul öncesi kurumlarına devam eden çocukların ebeveynleri ile öğretmenler düzenli olarak toplantılar yaparak uygun ebeveyn tutumları anlatılabilir.

- Günümüzde en etkili iletişim aracı olan televizyonlarda ebeveyn tutumlarını konu alan kamu spotlarının hazırlanarak ulusal veya uluslararası kanallarda yayınlatılabilir.

- İstenmeyen tutumların olumsuz etkilerini en aza indirgenebilmesi ve demokratik bir tutum içinde çocuğun yetiştirilmesi için sadece anne babalara eğitimler verilmemeli, çocuğun sosyal çevresinde olan diğer bireylere de bu eğitimler düzenlenmelidir.

\section{KAYNAKÇA}

Aksaray, S. (1992). Adolesanların benlik imajlarını etkileyen etmenlerden ana-baba tutum algısı (Yayımlanmamış yüksek lisans tezi). Çukurova Üniversitesi Sosyal Bilimler Enstitüsü, Adana. 
Alpoğuz, D. U. (2014). Algllanan ana-baba tutumlarının ilköğretim öğrencilerinin okumaya yönelik tutumlarına ve Türkçe dersi akademik başarılarına etkisi (Yayınlanmamış yüksek lisans tezi). Ahi Evran Üniversitesi Sosyal Bilimler Enstitüsü, Kırşehir.

Aksoy, A., Kılıç, Ş. ve Kahraman, Ö. (2009). Asya kültürlerinde ebeveynlik stilleri ve uygulaması. Çukurova Üniversitesi Sosyal Bilimler Enstitüsü Dergisi, 18(2), 14-25.

Arı M, Bayhan P, Artan İ. (1997). Farklı ana-baba tutumlarının 4-11 yaş grubu çocuklarında görülen problem durumlarına etkisinin araştırılması. 10. Ya-Pa Okul Öncesi Eğitimi ve Yaygınlaştırılması Semineri, İstanbul: Ya-Pa Yayınları.

Ayyıldız, T. (2005). Zonguldak il merkezinde 0-6 yaş çocuğu olan annelerin çocuk yetiştirme tutumları (Yayımlanmamış yüksek lisans tezi). Zonguldak Karaelmas Üniversitesi Sosyal Bilimler Enstitüsü, Zonguldak.

Baydar, N., Küntay, A., Gökşen, F., Yağmurlu, B. ve Cemalcılar, Z. (2010). Türkiye'de erken çocukluk gelişim ekolojileri araştırması, 1 Mayıs 2015 tarihinde http://www.manevisosyalhizmet.com/wp-content/uploads/2014/01/erkencocuklukgeli simekolojileriarastirmasi.pdf adresinden alınmıştır.

Cenk, D. ve Demir, A. (2015). The relationship between parenting style, gender and academic achievement with optimism among turkish adolescents. Current Psychology, 9(35), 720-728.

Demiriz, S. ve Öğretir, D. A. (2007). Alt ve üst sosyo-ekonomik düzeydeki 10 yaş çocuklarının anne tutumlarının incelenmesi. Kastamonu Eğitim Dergisi, 15(1), 105-122.

Demirutku, K. (2007). Parenting styles, internalization of values, and self-concept. (Yayınlanmamış doktora tezi). Orta Doğu Teknik Üniversitesi Sosyal Bilimler Enstitüsü, Ankara.

Durmuşoğlu Saltalı, N. ve Arslan, E. (2012). Ebeveyn tutumlarının anasınıfına devam eden çocukların sosyal yetkinlik ve içe dönüklük davranışını yordaması, Illkögretim Online, 11(3), 729-737.

Grigorenko, E.L. ve Sternberg. R.J. (2000). Elucidating the etiology and nature of beliefs about parenting styles. Developmental Science, 3 (1), 93-112.

İnan Kızıltepe, G., Uyanık, Ö., Özsüer, S. ve Can Yaşar, M. (2013). 61-72 aylık çocukların demokratik tutum ve davranışlarının anne görüşlerine göre değerlendirilmesi. TSA Dergisi, 17(3), 227-244.

Karabulut Demir, E. ve Şendil, G. (2008). Ebeveyn tutum ölçeği (ETÖ). Türk Psikoloji Yazıları, $11(21), 15-25$.

Karasar, N. (2009). Bilimsel araştırma yöntemleri. Ankara: Nobel Yayıncılık.

Kapıkıran, N. A, Bora İvrendi, A. ve Adak, A.(2005). Okul öncesi çocuklarında sosyal beceri: durum saptaması. Pamukkale Eğitim Fakültesi Dergisi, 19 (3), 1-8.

Mızrakçı, Ş. (1994). Annelerin çocuk yetiştirme tutumlarına etki eden faktörler: Demografik özellikleri, kendi yetiştiriliş tarzı, çocuk gelişimine ilişkin bilgi düzeyleri ve çocuğun mizacına ilişkin algıları (Yayımlanmamış yüksek lisans tezi). Ege Üniversitesi Sosyal Bilimler Enstitüsü, İzmir.

Ömeroğlu, F. (1998). Okul öncesi dönemde çocuğun terbiyesinde annenin rolü ve annelerin çocuk yetiştirme tutumları (Yayımlanmamış doktora tezi). Marmara Üniversitesi Sosyal Bilimler Enstitüsü, İstanbul. 
Özben, Ş. ve Argun, Y. (2002). Okul öncesi çocukların anne-babalarının çocuk yetiştirme tutumları ile ilgili değişkenlerin incelenmesi. Dokuz Eylül Üniversitesi Buca Eğitim Fakültesi Dergisi, 14, 18-28.

Özbey, S. ve Alisinanoğlu, F. (2009). Okul öncesi eğitim kurumuna devam eden 60-72 aylık çocukların problem davranışlarının bazı değişkenlere göre incelenmesi. Uluslararası Sosyal Araştırmalar Dergisi, 2 (6), 493-517.

Özerk, H. (2006). Anne-babaların çocuk yetiştirmeye ilişkin tutumlarının anne-babalık bilgi düzeylerinin ve 11-18 yaş grubu öğrencilerin kendilerini değerlendirmelerinin çeşitli değişkenler ve aralarındaki ilişki açısından incelenmesi (Yayınlanmamış doktora tezi). Ankara Üniversitesi Eğitim Bilimleri Enstitüsü, Ankara.

Poyraz, H. ve Özyürek, A. (2005). Okul öncesi 5-6 yaş çocuklarının problem davranışları ve

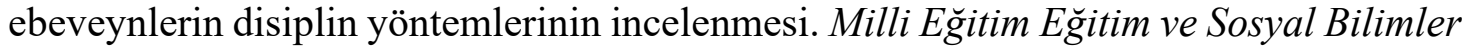
Dergisi, 33(166), 4 Ağustos 2016 tarihinde http://dhgm.meb.gov.tr/ yayimlar/dergiler/Milli_Egitim_Dergisi/166/index3-ozyurek.htm adresinden alınmıştır.

Savran, C. ve Kuşin, İ. (1997). Ana-babalar ile onların ana-babaları arasındaki çocuk yetiştirmeye yönelik tutum ilişkileri. 10. Ya-Pa. Okul Öncesi Ĕ̈itimi ve Yaygınlaştırılması Semineri. 22-25 Mayıs 1994. Ankara, 181-195.

Şahin, F. ve Özyürek, A. (2008). 5-6 yaş grubu çocuğa sahip ebeveynlerin demografik özelliklerinin çocuk yetiştirme tutumlarına etkisinin incelenmesi. Türk Eğitim Bilimleri Dergisi, 6 (3), 395-414.

Şanl1, D. (2007). Annelerin çocuk yetiştirme tutumlarını etkileyen etmenlerin incelenmesi (Yayımlanmamış yüksek lisans tezi). Dokuz Eylül Üniversitesi Sağlık Bilimleri Enstitüsü, İzmir.

Tortumluoğlu, G. (1999). Annelerin aile kavramını algılaması ve bunun çocuk yetiştirme tutumuna etkisi (Yayımlanmamış yüksek lisans tezi). Atatürk Üniversitesi Sağlık Bilimleri Enstitüsü, Erzurum.

Ulusoy, M. D., Demir, N. Ö. ve Baran, A. G. (2005). Ebeveynin çocuk yetiştirme biçimi ve ergen problemleri: Ankara ili örneği. Gazi Üniversitesi Türk Ĕ̈itim Bilimleri Dergisi, 3(3), 367-386.

Uyanık Balat, G. (2007). İlköğretime başlayan çocukların anne babalarının çocuk yetiştirme tutumlarının okul öncesi eğitimden yararlanma düzeylerine göre incelenmesi. Ĕgitim ve Bilim, 32(143), 89-99.

Uyanık, Ö., İnal Kızıltepe, G., Özsüer, S. ve Can Yaşar, M. (2013). 61-72 aylık çocukların demokratik tutum ve davranışlarının anne görüşlerine göre değerlendirilmesi. Türkiye Sosyal Araştırmalar Dergisi, 17(3), 227-243.

Von Der Lippe, A. (1999). The impact of maternal schooling and occupation on childrearing attitudes and behaviours in low income neighbourhoods in Cairo, Egypt. International Journal of Behavioral Development, 23(3), 703-729.

Yavuzer, H. (1999). Ana-baba ve çocuk (12. Bask1). İstanbul: Remzi Kitapevi.

Y1lmaz Bolat, E. (2011). Anne baba ĕgitiminin beş-altı yaş çocuğa sahip anne babaların çocuk yetiştirme tutum ve davranışlarına etkisinin incelenmesi (Yayımlanmamış doktora tezi). Ankara Üniversitesi Fen Bilimleri Enstitüsü, Ankara.

Yılmaz, A. (2001). Eşler arasındaki uyum, anne-baba tutumu ve benlik algısı arasındaki ilişkilerin gelişimsel olarak incelenmesi. Türk Psikoloji Dergisi, 16(47), 1-2. 